of food in the home cannot be successfully controlled by the health centre. Home economics and nutrition programmes cannot proceed smoothly when workers are besieged with requests for medical care. Diets cannot be greatly improved until agriculture and rural industry provide more income for families and until farmers are taught to produce for home use foods which are good supplementary sources of protein and other nutrients. Programmes in village improvement cannot forge ahead until illiteracy among adults is abolished and schools are built to accommodate a larger proportion of the village children.

Our first interest-the care and feeding of the young child-remains our major interest. It is also one of the primary interests of the village women. We believe that by demonstrating satisfactory methods of feeding young children, including the preparation and storage of foods, the use of simple but improved home equipment, and habits of living that protect the health of the young child, we can help village people towards better ways of life.

The studies we have made of living conditions, and some of the trials and demonstrations described in this paper, should be of value in guiding work along similar lines on a wider scale elsewhere in Egypt. This in fact is the main purpose of the project. The extent of the need and of the task to be accomplished is evident.

A picture of Egyptian village life and its problems in greater detail than the brief sketch provided by this paper will be found in articles by Ammar (1954), Lane (1835), Ayrout (1928) and Weir, Farag Rizk Hassan, Salah-el-Din Mohammed Attia \& Mohammed Abdel Kader (1952).

\title{
REFERENCES
}

Ammar, H. (1954). Growing up in an Egyptian Village. London: Routledge and Kegan Powell. Ayrout, F. (1928). The Fellaheen. Cairo: Schindler Press.

Lane, E. W. (1835). The Manners and Customs of the Modern Egyptians. (Everyman's Library edition, reprinted I954). London: J. M. Dent and Sons.

Weir, M., Farag Rizk Hassan, Salah-el-Din Mohammed Attia \& Mohammed Abdel Kader (1952). F. Egypt. publ. Hlth Ass. 27, 55 .

\section{Nutrition work in Burma past and present}

\section{By S. PostMus, Senior WHO Officer, Nutrition Project, Burma, Rangoon}

Though the number of nutrition workers in Burma has been very limited, various kinds of nutrition work have been carried out.

Dr U Maung Gale, Public Health Officer, later Director of Health Services, carried out nutritional and dietary surveys in seven areas between 1939 and I94I with the assistance of trained volunteers well known in the areas surveyed. His work (U Maung Gale, 1948) was published in 1948 by the Government Printing Office in Rangoon and may be summarized as follows:

The calorie and total-protein intake was not always sufficient and the animal protein did not always reach Swaminathan's ( 1938 ) standard of at least $25 \%$ of the 
total protein. The calcium content of the diet was generally low. The iron content was several times below the standard of $20 \mathrm{mg}$ daily. Many diets did not contain sufficient vitamin $\mathrm{A}$ and carotene. When no home-pounded rice was consumed the thiamine content was not sufficient. The riboflavin content of the diet could not be recorded at that time (1939 and 1940).

Often the ascorbic-acid content of the diet did not reach the standard of $30-50 \mathrm{mg} /$ consumption unit/day. (The FAO/WHO Nutrition Team found the average weight of the Burmese man to be $5^{\mathrm{I}} \cdot 3 \mathrm{~kg}$ and of the Burmese woman $45^{\cdot 5} \mathrm{~kg}$. Therefore the team considers that the calorie requirement could be lowered from 2600 (U Maung Gale, 1948) to $2100 \mathrm{Cal}$./head/day, so most of the diets U Maung Gale considered to contain insufficient calories contain, on this basis, sufficient calories. The low average weights also lower the requirements for total protein.)

The incidence of clinical signs of deficiency diseases was shown in the surveys to be in good concordance with the dietary data. The incidence of Bitot's spots and phrynoderma was not high; angular stomatitis and sore tongue were more frequently observed. Incidence of caries of the teeth was in many places very frequently recorded. Irregularities of the teeth were often observed.

Sharma (personal communication), in his survey of the expectant and nursing mothers, found that they frequently starve themselves because they think that a rich diet may cause abnormal growth of the foetus and end in difficult and painful labour. In general, their diet consists of large quantities of polished rice supplemented with small pieces of dried fish, some oil, and occasionally a small piece of mutton or a small helping of pulses, without any vegetables, fruits, eggs or milk. The common deficiency of thiamine proves in many cases fatal for the breast-fed babies. U Maung Gale (1948) mentions the same food habits among nursing and expectant mothers.

Radhakrishna Rao (1953), WHO Officer, mentions in his report the same deficiencies in the diets as U Maung Gale. He examined $22 \mathrm{I} 3$ persons: $20 \%$ were in a good nutritional condition, $72 \%$ were undernourished and $8 \%$ were malnourished. The main deficiencies observed by him were: angular stomatitis, xerosis of the conjunctivae, dental caries, anaemia, phrynoderma and glossitis. Bitot's spots, bleeding gums and dry skin were also observed, but to a much lesser extent. He recommended a programme of activities for a separate Division of Nutrition in the Directorate of Health Services. From these recommendations the Government of the Union of Burma and United Nations made an agreement for the provision of a nutrition project. Under this agreement WHO agreed to send a medical nutritionist and a biochemical technician, essential equipment and supplies, and promised fellowships for a nutritionist and biochemist. The FAO consented to provide a home economist-nutritionist, equipment and a fellowship in home economics-nutrition.

In August 1954 both the home economist and the medical nutritionist began their work. 'Their first work was to establish which local foods were included in the FAO food-composition table for international use (Chatfield, I949) and to sort out those foods for which data were lacking. One of the first tasks of the biochemist after his arrival will be to analyse the latter foods. Since no data on height and weight of 
the various age groups in Burma are available, schoolchildren in Rangoon were weighed and measured. At the same time their nutritional condition was determined and the occurrence of deficiency signs, caries and anaemia was registered. Till to-day ${ }_{4} 497$ Burmese boys, $125^{8}$ Burmese girls, 622 Chinese boys and 410 Chinese girls have been examined. The frequency of the various deficiency signs and the nutritional condition of the children are shown in Tables $\mathbf{I}$ and 2.

Table I. Percentage incidence of deficiency signs among schoolchildren in Rangoon

\begin{tabular}{lccccc}
\multicolumn{1}{c}{ Sign } & \multicolumn{2}{c}{ Burmese } & & Boys & Girls \\
Anaemia & Boys & Girls & & $24 \cdot 0$ & 25.4 \\
Angular stomatitis & 20.8 & 34.6 & & 2.6 & $2 \cdot 2$ \\
Caries & 19.0 & 14.5 & & $41 \cdot 3$ & $38 \cdot 2$ \\
Xerophthalmia & 28.0 & 30.7 & & 0 & 0
\end{tabular}

Table 2. Nutritional condition of schoolchildren in Rangoon

\begin{tabular}{lcccc} 
& \multicolumn{3}{c}{ Nutritional state } \\
\cline { 3 - 5 } Type of child & $\begin{array}{c}\text { No. } \\
\text { examined }\end{array}$ & $\begin{array}{c}\text { Good } \\
(\%)\end{array}$ & $\begin{array}{c}\text { Moderate } \\
(\%)\end{array}$ & $\begin{array}{c}\text { Bad } \\
(\%)\end{array}$ \\
Burmese boy & 1497 & $8 \cdot 0$ & 77.8 & $14 \cdot 2$ \\
Burmese girl & 1258 & $24 \cdot 9$ & $70 \cdot 3$ & 4.8 \\
Chinese boy & 622 & $20 \cdot 1$ & $76 \cdot 5$ & 3.4 \\
Chinese girl & 410 & 11.0 & 80.2 & 8.8
\end{tabular}

To give an explanation of the differences between the Burmese and the Chinese children is not easy. Generally speaking, the Chinese diet is richer in animal protein and vegetables than the Burmese diet. However, the data of the dietary surveys carried out in the vicinities inhabited by the schoolchildren are so few that we are not yet able to give a definite opinion. The co-operation of the parents, too, was very poor so that other methods had to be found, sometimes with the assistance of the Lady Health Visitors.

Caries is seen not only in the deciduous teeth but also in the permanent ones. In most cases it is a hypoplasia of the enamel. Jolliffe considers this among other reasons to be a result of lack of vitamin D (Jolliffe, Tisdall \& Cannon, 1950). This is quite possible in Burma since during the rainy season from the end of May until October the sun appears only very infrequently. Other symptoms of rickets were also frequently observed.

In the rural districts in the environs of Rangoon the same deficiencies were found as in Rangoon. The diet in these regions was the same as found by U Maung Gale (1948): nearly always highly milled rice in large quantities, little leafy vegetables and animal foods, very little fruit and only negligible amounts of milk and milk products.

Dietary and nutritional surveys were also carried out in:

I. Maymyo District among II6 families (Upper Burma).

2. Lashio District in the Northern Shan States among sixty-three families. 
3. Myitkyina District in the Kachin States among 174 families.

4. Payagyi District, in the rice-producing zone of the Irrawaddy Delta in Lower Burma, among 147 families.

5. Rangoon dietary surveys are still being carried out but these data are not yet available.

All diets consisted of large quantities of highly milled rice in Maymyo, Lashio and Payagyi Districts, but in most of the villages of Myitkyina District undermilled rice was consumed. In nearly all the villages of Maymyo, Lashio and Payagyi Districts the daily consumption of vegetables was less than $100 \mathrm{~g}$, in Myitkyina it was $125 \mathrm{~g}$. Usually $50 \%$ of the vegetables were leafy ones. Pulses were not very popular, the average daily consumption was never more than $25 \mathrm{~g}$. In the Buddhist villages the consumption of animal foods was lower than in the non-Buddhist villages. (Buddhists do not take life and many object to the consumption of animal foods.) The average daily consumption of fruits was usually below $5 \circ \mathrm{g}$; in one fruit-growing village it was $74 \mathrm{~g}$.

Only in villages inhabited by Nepalese (Gurkha) milk sellers, milk and milk products were consumed in bigger quantities than the usual Io- $5 \mathrm{~g}$. In one Nepalese village the milk consumption was $307 \mathrm{~g}$; the frequency of angular stomatitis was here only $2 \cdot 8 \%$, whereas in the non-milk-drinking villages 27.3 of the persons surveyed showed this deficiency sign.

In the prosperous rice-producing villages of Payagyi District the consumption of ngapi (pickled, fermented fish or shrimp paste) was very high, $40-50 \mathrm{~g}$, in the other districts it varied from $\circ$ to $I_{5} \mathrm{~g}$.

Although the diets in these various districts show differences as far as the food consumption is concerned, thay all had in common deficiencies in calcium, riboflavin, and vitamin $A$.

The deficiency signs found in the nutritional surveys, xerophthalmia, phrynoderma, hyperkeratosis of the skin, angular stomatitis, caries of the teeth, pyorrhoea and retracted gums, corresponded to the deficiencies in the diets. In Lashio District many cases of goitre II and III were observed. In one village even some cretins, cretinoids and deaf-mutes were met. Further inquiry in this region is necessary and will be carried out in the next dry season.

The clinic for expectant and nursing mothers in Rangoon was repeatedly visited, where Sharma's observations (personal communication) regarding the diets could be confirmed. Nearly $50 \%$ of the visiting nursing and expectant mothers had no knee-joint reflexes and had other symptoms of thiamine deficiency.

The weaning diet of the young children is usually very primitive. Even infants and babies are fed with rice, where breast feeding is insufficient. The mother chews the cooked rice to soften it and then feeds it to the baby. In the poorer families rice is the only weaning diet of the babies; the better situated feed their babies with home-made biscuits, sometimes with Horlicks and other patent foods. Only very seldom milk or milk products are used.

In the preparation of the rice are also many wrong habits. The washing of rice is very extensive. Usually it is washed until the water is completely clear. Furthermore, 
the rice is boiled in a surplus of water, which is discarded when the rice is well done. In this manner very little of the already very low thiamine content of the highly milled rice is left over. The preparation of vegetables can also cause losses of vitamins. Some are cooked with oil, salt and ngapi, in which event the cooking water is not discarded but consumed with the vegetables. Other leafy vegetables are cooked until tender and then the cooking water is discarded. Usually too much cooking water is used.

All these wrong food habits and methods of preparation must be fought. The Government is particularly active in the propaganda for the consumption of undermilled rice (san lon nyo). But far more has to be done in this field. Therefore the FAO home-economist--nutritionist has begun to instruct groups of people who work amongst, and are trusted by, the population, public-health workers, nurses, social-welfare workers and mass educators and teachers. Part of the lectures are given with a translation in Burmese. Diets and foods that should be consumed at every meal with the rice (the 'basic three' for Burma)* are demonstrated during these lectures on the flannelboard. The importance of the consumption of undermilled rice is explained on the flannelboard by demonstrating a longitudinal section of a paddy grain, which can be taken apart while explaining.

Various posters have been drafted, one on the correct method of washing rice, one on the choice and the preparation of vegetables and one on the basic three for Burma. During some field surveys short talks adapted to the specific needs of the area are given to the local workers and villagers. UNICEF is providing milk powder and fish-liver oil capsules to the Government under the Maternal and Child Health Programme for feeding of women and children in Maternal and Child Health Centres, schools, children's institutions and hospitals. Up to September 1954 $4,500,000$ fish-liver oil capsules had been distributed. In 1954 the Government distributed vitamin B-complex tablets containing $2 \mathrm{mg}$ thiamine, $3 \mathrm{mg}$ riboflavin and $20 \mathrm{mg}$ nicotinic acid to 544,270 patients; $10 \%$ of these people were pregnant mothers, $14 \%$ nursing mothers, $17 \%$ children from o to 3 years and $59 \%$ children older than 3 years.

The School Health Division carried out medical examinations of 100,000 schoolchildren in $35^{\circ}$ schools in Rangoon and asked UNICEF for skim-milk powder for $15 \%$ of the total number of schoolchildren in Rangoon. (However, the surveys done in the Rangoon schools by the nutrition team show that a far higher percentage of the children are in definite need of milk feeding.) School Health Programmes are operative in Mandalay, Bassein and Moulmein, and other towns will follow. A special problem is the many villages in Burma where no school or Maternal and Child Health Centre exists, where no milk can be distributed at all.

School feeding as known in other countries does not exist in Burma. However, plans for school feeding, or at least the distribution of a snack supplying those nutrients

\footnotetext{
* Eat with your undermilled rice every day one or more foods out of these three groups: (a) fish, ngapi, shrimps, meat, chicken, eggs, milk or pulses; (b) leafy vegetables (dark green), tubers with red or orange flesh, e.g. sweet potatoes or young orange maize; (c) fruits with yellow or orange flesh, e.g. bananas, pawpaw, jack-fruit, oranges, pineapple, mangoes; for vitamin $C$ Indian gooseberries and red peppers.
} 
most lacking in the diet, have been made in co-operation with UNICEF and the Government. Fish flour for this purpose has been sent to the country to be used first on an experimental basis. However, the equipment for a test kitchen is not available yet and without extensive preparation, acceptability and preference tests, the eventual introduction of fish flour in the diet is practically impossible. The Nutrition Team urgently needs the biochemist and the laboratory equipment, since many suppositions must be corroborated by experimental control.

Summarizing, it may be stated that, although valuable nutrition work has already been carried out in Burma, much more has to be done to evaluate and improve the nutritional and dietary situation in that country. Fortunately the Government proved, by requesting an extension of the services of the international personnel of the project, that it realizes the need for this work. That the international organizations realize the importance, becomes clear through the fact that not only WHO and FAO are assisting Burma in this field, but that the Ford Foundation has granted a large sum of money for equipment and fellowships for in-service training and that the Colombo Plan allows the provision of the money for fellowships in the nutrition field.

\section{REFERENCES}

Aykroyd, W. A. (1948). Spec. Rep. Indian Res. Fd, no. I6.

Chatfield, C. (1949). F.A.O. nutr. Stud. no. 3.

Jolliffe, N., Tisdall, F. F. \& Cannon, P. R. (1950). In Clinical Nutrition, p. 84. [N. Jolliffe, F. F. Tisdall and P. R. Cannon, editors.] New York: Harper and Brothers.

Radhakrishna Rao (1953). Final Report to the Regional Director WHO. Geneva: World Health Organization.

Swaminathan, M. (1938). Indian F. med. Res. 26, 113.

U Maung Gale (1948). Nutritional and Dietary Surveys in Burma. Rangoon: Government Printing Office. 